\title{
A Practical Synthesis of Thioflavones and Heterocyclic Analogues by Intramolecular Rearrangement of $S$-2-Acetophenyl Benzothioates as a Key Step
}

\author{
Jae In Lee* and Min Jung Kim \\ Department of Chemistry and Plant Resources Research Institute, College of Natural Science, Duksung Women's University, \\ Seoul 132-714, Korea.*E-mail: jilee@duksung.ac.kr \\ Received January 17, 2010, Accepted February 17, 2011
}

Key Words : Thioflavones, Condensation, Cyclization, Rearrangement, Cyclodehydration

The thioflavone (2-phenyl-4H-1-benzothiopyran-4-one) derivatives, thio analogues of flavones, have drawn considerable attention because of their profound pharmacological activities such as antiviral and inhibitory effect of steroid sulfatase (STS). ${ }^{1}$ Moreover, 3-enynyl substituted thioflavones exhibit highly potent antitumor and anticarcinogenic effect. ${ }^{2}$ In general, thioflavones are synthesized by the condensation of thiophenols with ethyl benzoylacetates in hot polyphosphoric acid in low to moderate yields. ${ }^{3}$ Similarly, subsequent cyclization of $\beta$-(arylthio)cinnamates, prepared by the 1,4-addition of aryl thiolates to aryl propiolates, with hot polyphosphoric acid affords the thioflavones. ${ }^{4}$ However, this method is not applicable for the synthesis of methoxy-substituted thioflavones because competitive cyclization between the cinnamyl aromatic ring and the sulfur-bearing ring occurs when the cinnamyl ring is activated by methoxy substituent.

To circumvent these drawbacks the reaction of $S$-aroyl derivatives of thiosalicylic acid with $\mathrm{Ph}_{3} \mathrm{P}=\mathrm{C}=\mathrm{C}=\mathrm{N}-\mathrm{Ph}^{5 \mathrm{a}, \mathrm{b}}$ or $\mathrm{Ph}_{3} \mathrm{P}=\mathrm{CHSiMe}_{3}{ }^{5 \mathrm{c}}$ and 2-(acylmercapto)phenacyl bromides with $\mathrm{Ph}_{3} \mathrm{P}^{6}$ has been developed, where the acylphosphorane intermediates undergo intramolecular Wittig cyclization to afford the thioflavones in moderate to high yields. However, this reaction proceeds in multiple steps from thiosalicylic acid at reflux temperature and the separation of phenyl isocyanate is often tedious. The condensation of polylithiated $N$-benzoylhydrazones ${ }^{7 \mathrm{a}}$ and acetoanilides ${ }^{7 \mathrm{~b}}$ using an excess LDA with methyl salicylate, followed by cyclization/ acidic hydrolysis affords the thioflavones in moderate to high yields. Also, the condensation of $\beta$-keto sulphoxide derivatives, ${ }^{8}$ derived from methyl 2 -mercaptobenzoate and sodium methylsulphinylmethide, with benzaldehydes affords the thioflavones after elimination of sulfoxide at reflux temperature in low total yields.

Alternatively, thioflavones are synthesized via thioflavanones. For instance, the cyclization of 3-phenylthiopropionic acid derivatives with $\mathrm{Bi}\left(\mathrm{NTf}_{2}\right)_{3}{ }^{9}$ or silver chalconates ${ }^{10}$ derived from 2'-mercaptoacetophenone and benzaldehydes affords the thioflavanones, which are successively dehydrogenated with DDQ to give the thioflavones at reflux temperature. The derivatives of thioflavanones such as their 1oxides $^{11}$ and spirothiadiazolines ${ }^{12}$ are also dehydrogenated with $\mathrm{Ac}_{2} \mathrm{O} / \mathrm{TsOH}$ and ceric ammonium nitrate, respectively, to give the thioflavones after elimination of $\mathrm{AcOH}$ and degradation of spirodiazoline ring, respectively, at high temperature in multiple steps. Recently, the 1,4-addition of alkynones which are prepared from the palladium catalyzed coupling of $o$-haloaroyl chlorides and terminal alkynes with $\mathrm{NaSH}$ in refluxing EtOH affords the thioflavones in moderate to high yields and this method is applicable for the synthesis of heterocyclic analogues of thioflavones. ${ }^{13}$

As part of our continuing search for thioflavonoids, ${ }^{14}$ we describe a new and practical synthesis of thioflavones and heterocyclic analogues via 1-(2-mercaptophenyl)-3-(hetero)aryl-1,3-propanediones from 2'-mercaptoacetophenone. We became interested in the synthesis of heterocyclic analogues of thioflavones in which 2-phenyl group is replaced by heteroaromatic group because a few synthetic methods are reported. ${ }^{6,15}$

2'-Mercaptoacetophenone (1) was efficiently prepared by the treatment of thiosalicylic acid with 3 equiv of methyllithium in DME for $1 \mathrm{~h}$ between $-15{ }^{\circ} \mathrm{C}$ and $0{ }^{\circ} \mathrm{C}$ in $82 \%$

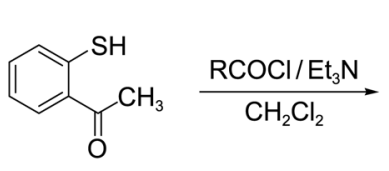

1

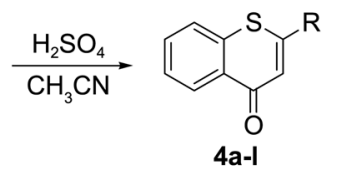<smiles>[R]C(=O)Sc1ccccc1C(C)=O</smiles>

2a-I
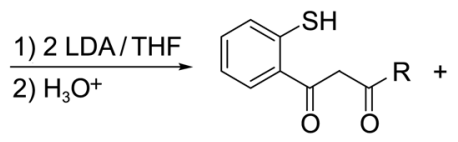

$3 a-1$

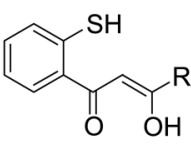

$3 a^{\prime}-1 '$

$\mathrm{R}=\mathrm{C}_{6} \mathrm{H}_{5}(\mathbf{a}), 2-\mathrm{Cl}-\mathrm{C}_{6} \mathrm{H}_{4}(\mathbf{b}), 4-\mathrm{Cl}_{-} \mathrm{C}_{6} \mathrm{H}_{4}(\mathbf{c}), 2-\mathrm{CH}_{3}-\mathrm{C}_{6} \mathrm{H}_{4}(\mathbf{d}), 4-\mathrm{CH}_{3}-\mathrm{C}_{6} \mathrm{H}_{4}(\mathbf{e})$,

2- $\mathrm{CH}_{3} \mathrm{O}-\mathrm{C}_{6} \mathrm{H}_{4}$ (f), 4- $\mathrm{CH}_{3} \mathrm{O}-\mathrm{C}_{6} \mathrm{H}_{4}(\mathbf{g}), 3,4-\left(\mathrm{CH}_{3} \mathrm{O}\right)_{2}-\mathrm{C}_{6} \mathrm{H}_{3}(\mathbf{h})$,

3,4,5-( $\left(\mathrm{CH}_{3} \mathrm{O}\right)_{3}-\mathrm{C}_{6} \mathrm{H}_{2}$ (i), 2-furyl (j), 2-thienyl (k), 3-pyridyl (I) 
yield according to the previous report with modification. ${ }^{16}$ The $S$-aroylation of $\mathbf{1}$ with aroyl chlorides in the presence of triethylamine proceeded readily in dichloromethane for $0.5 \mathrm{~h}$ at $0{ }^{\circ} \mathrm{C}$. After usual workup, the residue was purified by short pathway silica gel column chromatography to give $S$-2-acetophenyl benzothioates (2a-i) in 90-98\% yields (Scheme 1). The $S$-heteroaroylation of 1 with heteroaroyl chlorides proceeded equally well to afford $S$-2-acetophenyl heteroaroylthioates $(\mathbf{2} \mathbf{j}-\mathbf{l})$ in $\mathbf{7 8 - 8 8 \%}$ yields.

The key step in thioflavones synthesis involves the intramolecular rearrangement of $\mathbf{2}$ to 1-(2-mercaptophenyl)-3(hetero)aryl-1,3-propanediones (3). Initially the treatment of $S$-2-acetophenyl benzothioate (2a) with 1 equiv of LDA for $20 \mathrm{~h}$ between $0{ }^{\circ} \mathrm{C}$ and room temperature to afford 1-(2mercaptophenyl)-3-phenyl-1,3-propanedione $\left(\mathbf{3 a}+\mathbf{3} \mathbf{a}^{\prime}\right)$ after acidic workup in only $47 \%$ yield. However, the rearrangement of $\mathbf{2 a}$ to $\mathbf{3} \mathbf{a}+\mathbf{3} \mathbf{a}^{\prime}$ was completed with 2 equiv of LDA within $0.5 \mathrm{~h}$ between $-15{ }^{\circ} \mathrm{C}$ and $0{ }^{\circ} \mathrm{C}$. It seems that an additive equimolar amount of LDA abstracts the $\mathrm{C}_{2}$ methylene proton of 1-(2-lithiumthiophenoxy)-3-phenyl-1,3-propanedione intermediate, produced by the intramoleular rearrangement of $\mathbf{2 a}$, to shift equilibrium to the more stabilized conjugated lithium alkoxide intermediate. Thus the rearrangement of $\mathbf{2 a - i}$ to $\mathbf{3 a - i}$ was carried out using 2 equiv of LDA in THF. However, the rearrangement of $S$-2acetophenyl heteroaroylthioates $(\mathbf{2} \mathbf{j}-\mathbf{l})$ showed several spots in TLC under the corresponding conditions. The rearrangement of $\mathbf{2 j}$-l was successfully accomplished using 2 equiv of LDA for $1 \mathrm{~h}$ between $-78{ }^{\circ} \mathrm{C}$ and $-40{ }^{\circ} \mathrm{C}$. After usual acidic workup, the condensed residue was recrystallized twice in $15 \%$ EtOAc/ $n$-hexane to give 3 as yellow solids in $78-94 \%$ yields. The ${ }^{1} \mathrm{H}$ NMR spectra of $\mathbf{3}$ showed $\mathrm{C}_{2}$ methylene signals at 3.15-3.97 ppm with two doublets interestingly and 3 exist mostly as keto forms.

To find out an optimum solvent for the cyclodehydration of $3,3 \mathbf{a}+\mathbf{3} \mathbf{a}^{\prime}$ was treated with 1 equiv of sulfuric acid in various solvents such as $\mathrm{HOAc}, \mathrm{CH}_{3} \mathrm{CN}, \mathrm{EtOH}$, and $\mathrm{THF}$ at room temperature and the desired thioflavone (4a) was obtained in $96 \%, 96 \%, 95 \%$, and $94 \%$ yield, respectively, after $0.5 \mathrm{~h}, 1 \mathrm{~h}, 36 \mathrm{~h}$, and $48 \mathrm{~h}$, respectively. Despite of the rapidity of cyclodehydration in HOAc, it is corrosive, pungent, and troublesome to separate and therefore $\mathrm{CH}_{3} \mathrm{CN}$ was chosen as a suitable solvent for the cyclodehydration of 3. The cyclodehydration of $\mathbf{3} \mathbf{a}+\mathbf{3} \mathbf{a}^{\prime}$ using 1 equiv of poly-

Table 1. Preparation of compounds 2, 3, and thioflavones and heterocyclic analogues 4 from 2'-mercaptoacetophenone

\begin{tabular}{|c|c|c|c|c|c|c|c|c|c|}
\hline \multirow{2}{*}{ Entry } & \multirow{2}{*}{ Product } & \multicolumn{3}{|c|}{ Isolated yields, $\%^{a}$} & \multirow{2}{*}{ Entry } & \multirow{2}{*}{ Product } & \multicolumn{3}{|c|}{ Isolated yields, $\%^{a}$} \\
\hline & & 2 & 3 & 4 & & & 2 & 3 & 4 \\
\hline $\mathbf{a}$ & & 96 & 82 & $96(76)$ & $\mathbf{g}$ & & 98 & 90 & $90(79)$ \\
\hline $\mathbf{b}$ & & 94 & 80 & $91(68)$ & $\mathbf{h}$ & & 95 & 86 & $96(78)$ \\
\hline c & & 90 & 88 & $86(68)$ & $\mathbf{i}$ & & 96 & 88 & $92(78)$ \\
\hline d & & 92 & 91 & $96(80)$ & $\mathbf{j}$ & & 94 & 88 & $97(80)$ \\
\hline $\mathbf{e}$ & & 91 & 91 & $98(81)$ & $\mathbf{k}$ & & 93 & 85 & $94(74)$ \\
\hline $\mathbf{f}$ & & 98 & 94 & $90(83)$ & 1 & & 87 & 78 & $97(66)$ \\
\hline
\end{tabular}

${ }^{{ }^{a}}$ The numbers in parentheses indicate the overall yields of three steps from 2'-mercaptoacetophenone 1 . 
phosphoric acid in $\mathrm{CH}_{3} \mathrm{CN}$ at room temperature was also examined, but the reaction was rather sluggish and afforded 4a after $48 \mathrm{~h}$ in $95 \%$ yield. Thus, the cyclodehydration of $\mathbf{3}$ was carried out using sulfuric acid in $\mathrm{CH}_{3} \mathrm{CN}$ at room temperature. After usual basic workup, the residue was recrystallized twice in $10 \% \mathrm{EtOAc} / n$-hexane to afford the thioflavones and heterocyclic analogues (4) in 86-98\% yields.

As shown in Table 1, various thioflavones and heterocyclic analogues were synthesized in overall high yields (66$83 \%$ ) from 2'-mercaptoacetophenone 1 . The reaction worked well both for the electron withdrawing substituent such as chloro group $(\mathbf{4 b}, \mathbf{4 c})$ and electron donating substituents such as methyl $(\mathbf{4 d}, \mathbf{4 e})$ and methoxy group (4f-4i) of 2substituted phenyl ring. The ortho-substituent on the phenyl ring of $\mathbf{4 b}, \mathbf{4 d}$, and $\mathbf{4 f}$ hardly influenced on the aroylation, rearrangement, and cyclodehydration. Furthermore, this method was applicable to the synthesis of heterocyclic thioflavones containing heteroaromatic ring such as 2-furyl (4j), 2-thienyl (4k), and 3-pyridyl group (4l) in high yields.

In conclusion the present method offers a practical synthesis of thioflavones and heterocyclic analogues from 2'-mercaptoacetophenone 1. It showed the advantage of high yields in each step, the versatility of the reaction under the mild conditions, and could be applied in the synthesis of heterocyclic thioflavones.

\section{Experimental Section}

Preparation of $\boldsymbol{S}$-2-Acetophenyl Benzothioate 2a (General Procedure). To a solution of 2'-mercaptoacetophenone $(761 \mathrm{mg}, 5.0 \mathrm{mmol})$ in dichloromethane $(20 \mathrm{~mL})$ was added triethylamine $(700 \mu \mathrm{L}, 5.0 \mathrm{mmol})$ and benzoyl chloride $(703 \mathrm{mg}, 5.0 \mathrm{mmol})$ at $0{ }^{\circ} \mathrm{C}$. After being stirred for $0.5 \mathrm{~h}$ at this temperature, the mixture was poured into saturated $\mathrm{NaHCO}_{3}$ solution $(30 \mathrm{~mL})$ and extracted with dichloromethane $(3 \times 20 \mathrm{~mL})$. The combined organic phases were dried over $\mathrm{MgSO}_{4}$, filtered, and concentrated in vacuo. The residue was purified by short pathway silica gel column chromatography using $30 \% \mathrm{EtOAc} / n$-hexane as an eluant to give $2 \mathbf{a}(1.23 \mathrm{~g}, 96 \%) .{ }^{1} \mathrm{H}$ NMR $\left(300 \mathrm{MHz}, \mathrm{CDCl}_{3}\right) \delta 8.00$ 8.04 (m, 2H), 7.68-7.71 (m, 1H), 7.57-7.63 (m, 2H), 7.44$7.53(\mathrm{~m}, 4 \mathrm{H}), 2.59(\mathrm{~s}, 3 \mathrm{H}) ;{ }^{13} \mathrm{C} \mathrm{NMR}\left(75 \mathrm{MHz}, \mathrm{CDCl}_{3}\right) \delta$ 200.9, 189.5, 143.8, 137.1, 136.4, 133.8, 131.2, 129.5, 128.8, 128.4, 127.6, 125.4, 29.4; FT-IR (film) 3060, 2923, $1682(\mathrm{C}=\mathrm{O}), 1580,1447,1355,1205,899,760,685 \mathrm{~cm}^{-1}$; Ms $m / z \quad(\%) 256 \quad\left(\mathrm{M}^{+}, 5\right), 151 \quad$ (31), 134 (10), 105 $\left(\mathrm{C}_{6} \mathrm{H}_{5} \mathrm{C} \equiv \mathrm{O}^{+}, 100\right), 77$ (93).

Preparation of 1-(2-Mercaptophenyl)-3-phenyl-1,3propanedione 3a (General Procedure). To a solution of $\mathbf{2 a}$ $(1.03 \mathrm{~g}, 4.0 \mathrm{mmol})$ in THF $(16 \mathrm{~mL})$ was added LDA $(1.8 \mathrm{M}$, $4.5 \mathrm{~mL}, 8.1 \mathrm{mmol})$ at $-15{ }^{\circ} \mathrm{C}$ under argon atmosphere. The stirring was continued for $0.5 \mathrm{~h}$ between $-15{ }^{\circ} \mathrm{C}$ and $0{ }^{\circ} \mathrm{C}$ and then the resulting yellow mixture was quenched with 1 $\mathrm{N}-\mathrm{HCl}(5 \mathrm{~mL})$, followed by evaporation of THF in vacuo. The mixture was poured into $0.5 \mathrm{~N}-\mathrm{HCl}(30 \mathrm{~mL})$, extracted with dichloromethane $(3 \times 20 \mathrm{~mL})$, and washed with brine
$(30 \mathrm{~mL})$. The combined organic phases were dried over $\mathrm{MgSO}_{4}$, filtered, and concentrated in vacuo. The residue was recrystallized twice in $15 \% \mathrm{EtOAc} / n$-hexane to give $\mathbf{3 a}+\mathbf{3} \mathbf{a}^{\prime}$ $(841 \mathrm{mg}, 82 \%)$ as a pale yellow solid. $\mathrm{mp} 118-119^{\circ} \mathrm{C}$ (lit. ${ }^{14 \mathrm{~b}}$ 116-118 $\left.{ }^{\circ} \mathrm{C}\right)$; ${ }^{1} \mathrm{H}$ NMR $\left(300 \mathrm{MHz}, \mathrm{CDCl}_{3}\right) \delta 8.09$ (dd, $J_{1}=$ $\left.8.2 \mathrm{~Hz}, J_{2}=1.5 \mathrm{~Hz}, 1 \mathrm{H}\right), 7.60-7.64(\mathrm{~m}, 2 \mathrm{H}), 7.30-7.40(\mathrm{~m}$, 4H), 7.14-7.19 (m, 2H), 3.38 (d, $J=16.3 \mathrm{~Hz}, 1 \mathrm{H}), 3.18$ (d, $J$ $=16.3 \mathrm{~Hz}, 1 \mathrm{H}), 2.93(\mathrm{~s}, 1 \mathrm{H}) ;{ }^{13} \mathrm{C} \mathrm{NMR}\left(75 \mathrm{MHz}, \mathrm{CDCl}_{3}\right) \delta$ $193.8,143.0,139.2,134.4,130.0,129.4,129.3,129.2$, 128.0, 126.0, 125.3, 85.9, 54.1; FT-IR (KBr) 3052, 1652 $(\mathrm{C}=\mathrm{O}), 1583,1435,1297,1110,857,761,719 \mathrm{~cm}^{-1} ; \mathrm{Ms} m / z$ (\%) $256\left(\mathrm{M}^{+}, 16\right), 238\left(\mathrm{M}^{+}-18,100\right), 151(46), 136(60), 105$ (79).

Preparation of Thioflavone 4a (General Procedure). A solution of 3a (769 mg, $3.0 \mathrm{mmol})$ and conc $\mathrm{H}_{2} \mathrm{SO}_{4}(160 \mu \mathrm{L}$, $3.0 \mathrm{mmol})$ in $\mathrm{CH}_{3} \mathrm{CN}(25 \mathrm{~mL})$ was stirred for $1 \mathrm{~h}$ at room temperature. After evaporation of $\mathrm{CH}_{3} \mathrm{CN}$, the mixture was poured into saturated $\mathrm{NaHCO}_{3}$ solution $(30 \mathrm{~mL})$ and extracted with dichloromethane $(3 \times 20 \mathrm{~mL})$. The combined organic phases were dried over $\mathrm{MgSO}_{4}$, filtered, and concentrated in vacuo. The residue was recrystallized twice in $10 \% \mathrm{EtOAc} / n$-hexane to give $\mathbf{4 a}(686 \mathrm{mg}, 96 \%)$ as a pale yellow solid. mp $125-126{ }^{\circ} \mathrm{C}$ (lit. $\left.{ }^{5 \mathrm{c}} 126{ }^{\circ} \mathrm{C}\right) ;{ }^{1} \mathrm{H}$ NMR $(300$ $\left.\mathrm{MHz}, \mathrm{CDCl}_{3}\right) \delta 8.56\left(\mathrm{dd}, J_{1}=8.2 \mathrm{~Hz}, J_{2}=1.3 \mathrm{~Hz}, 1 \mathrm{H}\right), 7.63-$ $7.72(\mathrm{~m}, 4 \mathrm{H}), 7.53-7.58(\mathrm{~m}, 1 \mathrm{H}), 7.48-7.52(\mathrm{~m}, 3 \mathrm{H}), 7.25(\mathrm{~s}$, $1 \mathrm{H}) ;{ }^{13} \mathrm{C} \mathrm{NMR}\left(75 \mathrm{MHz}, \mathrm{CDCl}_{3}\right) \delta 180.9,153.0,137.7$, 136.6, 131.6, 130.9, 130.8, 129.3, 128.6, 127.8, 127.0, 126.5, 123.5; FT-IR (KBr) 3066, $1621(\mathrm{C}=\mathrm{O}), 1588,1335$, 1099, 760, $696 \mathrm{~cm}^{-1}$; Ms $m / z(\%) 240\left(\mathrm{M}^{+}+2,5\right), 238\left(\mathrm{M}^{+}\right.$, 100), 210 (93), 165 (14), 136 (36), 108 (23).

$\mathbf{4 b}, \mathbf{4 c}$, and $4 \mathrm{e}-\mathrm{i}$ : All products were identified by means of ${ }^{1} \mathrm{H} /{ }^{13} \mathrm{C}$ NMR, FT-IR, and mass spectrometry and consistent with our previous results. ${ }^{14 \mathrm{~b}}$

\section{Selected Spectroscopic Data.}

2'-Methylthioflavone (4d): oil; ${ }^{1} \mathrm{H}$ NMR (300 MHz, $\left.\mathrm{CDCl}_{3}\right) \delta 8.58(\mathrm{~d}, J=7.9 \mathrm{~Hz}, 1 \mathrm{H}), 7.61-7.64(\mathrm{~m}, 2 \mathrm{H}), 7.54-$ $7.61(\mathrm{~m}, 1 \mathrm{H}), 7.26-7.37(\mathrm{~m}, 4 \mathrm{H}), 6.92(\mathrm{~s}, 1 \mathrm{H}), 2.39$ (s, 3H); ${ }^{13} \mathrm{C}$ NMR $\left(75 \mathrm{MHz}, \mathrm{CDCl}_{3}\right) \delta 180.9,154.0,138.8,136.5$, 136.1, 132.0, 131.4, 131.3, 130.2, 129.4, 129.1, 128.2, 126.7 (overlapped), 126.5, 20.3; FT-IR (KBr) 3070, $1626(\mathrm{C}=\mathrm{O})$, 1438, 1325, 1098, 755, $729 \mathrm{~cm}^{-1}$; Ms m/z (\%) $252\left(\mathrm{M}^{+}\right.$, 100), 223 (53), 136 (45), 115 (33), 108 (32).

2-Furyl-4H-1-benzothiopyran-4-one (4j): mp 140-141 ${ }^{\circ} \mathrm{C} ;{ }^{1} \mathrm{H} \mathrm{NMR}\left(300 \mathrm{MHz}, \mathrm{CDCl}_{3}\right) \delta 8.49(\mathrm{~d}, J=8.0 \mathrm{~Hz}, 1 \mathrm{H})$, 7.58-7.61 (m, 3H), 7.47-7.54 (m, 1H), 7.32 (s, 1H), 6.95 (d, $J=3.5 \mathrm{~Hz}, 1 \mathrm{H}), 6.57\left(\mathrm{dd}, J_{1}=3.5 \mathrm{~Hz}, J_{2}=1.8 \mathrm{~Hz}, 1 \mathrm{H}\right) ;{ }^{13} \mathrm{C}$ $\mathrm{NMR}\left(75 \mathrm{MHz}, \mathrm{CDCl}_{3}\right) \delta 180.9,149.4,145.6,141.2,136.7$, 132.0, 131.5, 128.9, 126.9, 119.3, 111.7; FT-IR (KBr) 3107, $1611(\mathrm{C}=\mathrm{O}), 1587,1334,1102,967,758,728 \mathrm{~cm}^{-1}$; Ms $\mathrm{m} / z$ (\%) $228\left(\mathrm{M}^{+}, 100\right), 200$ (67), 171 (47), 136 (33), 108 (18).

2-Thienyl-4H-1-benzothiopyran-4-one (4k): mp 128$129{ }^{\circ} \mathrm{C} ;{ }^{1} \mathrm{H}$ NMR $\left(300 \mathrm{MHz}, \mathrm{CDCl}_{3}\right) \delta 8.50(\mathrm{~d}, J=7.9 \mathrm{~Hz}$, $1 \mathrm{H}), 7.58-7.61(\mathrm{~m}, 2 \mathrm{H}), 7.47-7.56(\mathrm{~m}, 3 \mathrm{H}), 7.23(\mathrm{~s}, 1 \mathrm{H})$, $7.15\left(\mathrm{dd}, J_{1}=5.1 \mathrm{~Hz}, J_{2}=3.8 \mathrm{~Hz}, 1 \mathrm{H}\right) ;{ }^{13} \mathrm{C} \mathrm{NMR}(75 \mathrm{MHz}$, $\left.\mathrm{CDCl}_{3}\right) \delta 181.0,145.9,139.5,137.2,132.1,131.4,129.6$, 129.0, 128.9, 128.2, 127.7, 126.6, 121.8; FT-IR (KBr) 3086, $1605(\mathrm{C}=\mathrm{O}), 1586,1322,1103,781,715 \mathrm{~cm}^{-1}$; Ms $\mathrm{m} / z(\%)$ 
$244\left(\mathrm{M}^{+}, 100\right), 216$ (60), 136 (33), 108 (22).

3-Pyridyl-4H-1-benzothiopyran-4-one (4I): mp 162-163 ${ }^{\circ} \mathrm{C} ;{ }^{1} \mathrm{H}$ NMR $\left(300 \mathrm{MHz}, \mathrm{CDCl}_{3}\right) \delta 8.95(\mathrm{~d}, J=2.1 \mathrm{~Hz}, 1 \mathrm{H})$, $8.76(\mathrm{~d}, J=4.7 \mathrm{~Hz}, 1 \mathrm{H}), 8.56(\mathrm{~d}, J=7.7 \mathrm{~Hz}, 1 \mathrm{H}), 7.98(\mathrm{~d}, J$ $=8.0 \mathrm{~Hz}, 1 \mathrm{H}), 7.65-7.70(\mathrm{~m}, 2 \mathrm{H}), 7.56-7.63(\mathrm{~m}, 1 \mathrm{H}), 7.46$ $\left(\mathrm{dd}, J_{1}=8.0 \mathrm{~Hz}, J_{2}=4.9 \mathrm{~Hz}, 1 \mathrm{H}\right), 7.22(\mathrm{~s}, 1 \mathrm{H}) ;{ }^{13} \mathrm{C} \mathrm{NMR}(75$ $\left.\mathrm{MHz} \mathrm{CDCl}_{3}\right) \delta 180.8,152.1,149.8,148.1,137.6,134.7$, 133.0, 132.3, 131.2, 129.1, 128.5, 126.9, 124.7, 124.3; FT-IR (KBr) 3073, 3024, $1615(\mathrm{C}=\mathrm{O}), 1589,1325,1129,778,734$ $\mathrm{cm}^{-1}$; Ms m/z (\%) 239 (M $\left.\mathrm{M}^{+}, 100\right), 211$ (79), 136 (37), 108 (18).

Acknowledgments. This work was supported by Priority Research Centers Program through the National Research Foundation of Korea (NRF) funded by the Ministry of Education, Science and Technology (2010-0029692).

\section{References}

1. (a) Nakazumi, H.; Kobara, Y.; Kitao, T. J. Heterocyclic Chem. 1992, 29, 135. (b) Nussbaumer, P.; Lehr, P.; Billich, A. J. Med. Chem. 2002, 45, 4310. (c) Nussbaumer, P.; Winiski, A. P.; Billich, A. J. Med. Chem. 2003, 46, 5091. (d) Horvath, A.; Nussbaumer, P.; Wolff, B.; Billich, A. J. Med. Chem. 2004, 47, 4268.

2. (a) Pal, M.; Parasuraman, K.; Subramanian, V.; Dakarapu, R.; Yeleswarapu, K. R. Tetrahedron Lett. 2004, 45, 2305. (b) Pal, M.; Dakarapu, R.; Parasuraman, K.; Subramanian, V.; Yeleswarapu, K. R. J. Org. Chem. 2005, 70, 7179 .

3. (a) Razdan, R. K.; Bruni, R. J.; Mehta, A. C.; Weinhardt, K. K.; Papanastassiou, Z. B. J. Med. Chem. 1978, 21, 643. (b) Nakazumi, H.; Watanabe, S.; Kitaguchi, T.; Kitao, T. Bull. Chem. Soc. Jpn.
1990, 63, 847. (c) Wang, H.-K.; Bastow, K. F.; Cosentino, L. M.; Lee, K.-H. J. Med. Chem. 1996, 39, 1975. (d) Dekermendjian, K.; Kahnberg, P.; Witt, M.-R.; Sterner, O.; Nielsen, M.; Liljefors, T. $J$. Med. Chem. 1999, 42, 4343.

4. Wadsworth, D. H.; Detty, M. R. J. Org. Chem. 1980, 45, 4611.

5. (a) Kumar, P.; Rao, A. T.; Pandey, B. J. Chem. Soc., Chem. Commun. 1992, 1580. (b) Kumar, P.; Rao, A. T.; Pandey, B. Synth. Commun. 1994, 24, 3297. (c) Kumar, P.; Bodas, M. S. Tetrahedron 2001, 57, 9755.

6. Dhanak, D.; Keenan, R. M.; Burton, G.; Kaura, A.; Darcy, M. G.; Shah, D. H.; Ridgers, L. H.; Breen, A.; Lavery, P.; Tew, D. G.; West, A. Bioorg. \& Med. Chem. Lett. 1998, 8, 3677.

7. (a) French, K. L.; Angel, A. J.; Williams, A. R.; Hurst, D. R.; Beam, C. F. J. Heterocyclic Chem. 1998, 35, 45. (b) Angel, A. J.; Finefrock, A. E.; French, K. L.; Hurst, D. R.; Williams, A. R.; Rampey, M. E.; Studer-Martinez, S. L.; Beam, C. F. Can. J. Chem. 1999, 77, 94.

8. (a) Taylor, A. W.; Dean, D. K. Tetrahedron Lett. 1988, 29, 1845. (b) Kataoka, T.; Watanabe, S.; Mori, E.; Kadomoto, R.; Tanimura, S.; Kohno, M. Bioorg. \& Med. Chem. 2004, 12, 2397.

9. Cui, D.-M.; Kawamura, M.; Shimada, S.; Hayashi, T.; Tanaka, M. Tetrahedron Lett. 2003, 44, 4007.

10. (a) Somogyi, L. Synth. Commun. 1999, 29, 1857. (b) Konieczny, M. T.; Horowska, B.; Kunikowski, A.; Konopa, J.; Wierzba, K.; Yamada, Y.; Asao, T. J. Org. Chem. 1999, 64, 359.

11. Somogyi, L. Can. J. Chem. 2001, 79, 1159.

12. Somogyi, L. J. Heterocyclic Chem. 2009, 46, 399.

13. (a) Willy, B.; Muller, T. J. J. Synlett 2009, 1255. (b) Fuchs, F. C.; Eller, G. A.; Holzer, W. Molecules 2009, 14, 3814.

14. (a) Lee, J. I. Bull. Korean Chem. Soc. 2008, 29, 1263. (b) Lee, J. I. Bull. Korean Chem. Soc. 2009, 30, 710.

15. Strandtmann, M.; Klutchko, S.; Cohen, M. P.; Shavel, J. J. Heterocyclic Chem. 1972, 9, 171.

16. Topolski, M. J. Org. Chem. 1995, 60, 5588. 